\begin{tabular}{cc|c}
\hline Tar. Bil. Der. & Tarım Bilimleri Dergisi & Journal of Agricultural Sciences \\
& $\begin{array}{c}\text { Dergi web sayfası: } \\
\text { www.agri.ankara.edu.tr/dergi }\end{array}$ & Journal homepage: \\
& www.agri.ankara.edu.tr/journal
\end{tabular}

\title{
The Effect of Diflufenican and Its Mixture with S-metolachlor and Metribuzin on Nitrogenase and Microbial Activity of Soil under Yellow Lupine (Lupinus luteus L.)
}

Alicja NIEWIADOMSKA ${ }^{\mathrm{a}}$, Grzegorz SKRZYPCZAK ${ }^{\mathrm{b}}$, Lukasz SOBIECH ${ }^{\mathrm{b}}$, Agnieszka WOLNAMARUWKA $^{\mathrm{a}}$, Klaudia BOROWIAK ${ }^{\mathrm{c}}$, Anna BUDKA ${ }^{\mathrm{d}}$

${ }^{a}$ Poznan University of Life Sciences, Department of General and Environmental Microbiology, 60-656 Poznan, POLAND

${ }^{b}$ Poznan University of Life Sciences, Department of Agronomy, 60-656 Poznan, POLAND

${ }^{c}$ Poznan University of Life Sciences, Department of Ecology and Environmental Protection, 60-649 Poznan, POLAND

dPoznan University of Life Sciences, Department of Mathematical and Statistical Methods, 60-637 Poznan, POLAND

\section{ARTICLE INFO}

Research Article DOI: 10.15832/ankutbd.446412

Corresponding Author: Alicja NIEWIADOMSKA, E-mail: alicja.niewiadomska@onet.eu, Tel: +0048 (61) 8487195

Received: 04 January 2016, Received in Revised Form: 14 June 2016, Accepted: 15 June 2016

\begin{abstract}
The aim of the study was to evaluate the effect of the active substance of diflufenican and its combination with s-metolachlor or metribuzin, applied to yellow lupine, on the nitrogenase activity, the population size of selected groups of microorganisms, the activity of soil enzymes and their sensitivity to the tested preparations. All analysed preparations caused a reduction in the total number of bacteria and the number of actinobacteria and oligotrophic bacteria at the beginning of the vegetation period of yellow lupine. In the combination where diflufenican was used separately a stimulatory effect on nitrogenase activity was observed. The research revealed very high sensitivity of dehydrogenases and acid phosphatase to the soil contamination caused by application of all the tested herbicides. The dehydrogenases activity values were closely correlated with reduced populations of the groups of microorganisms. Diflufenican applied separately caused a relatively small negative effect on biological soil properties and consequently could have a smaller negative effect on soil environment contamination in comparison to other variants.
\end{abstract}

Keywords: Active substances; Herbicides; Number of microorganisms; Leguminous plants; Soil enzyme activity

\section{Diflufenican ve Diflufenican'ın S-metolachlor ve Metribuzin ile Karışımlarının Sarı Acı Bakla (Lupinus luteus L.) Bitkisinde Nitrojenaz Enzimi ve Topraktaki Mikrobiyal Aktivite Üzerine Etkisi}

\section{ESER BÍLGÍSİ}

Araştırma Makalesi

Sorumlu Yazar: Alicja NIEWIADOMSKA, E-posta: alicja.niewiadomska@onet.eu, Tel: +0048 (61) 8487195

Geliş Tarihi: 04 Ocak 2016, Düzeltmelerin Gelişi: 14 Haziran 2016, Kabul: 15 Haziran 2016 


\section{ÖZET}

Bu çalışmanın amacı diflufenican ve diflufenicanın s-metolachlor veya metribuzin ile birlikte aktif madde bazında sarı acı bakla bitkisine uygulanmasının nitrogenaz aktivitesi, kimi mikroorganizma gruplarının sayıları ve toprak enzim aktivitesine etkisi ile enzimlerin uygulanan herbisitlere duyarlılıklarını belirlemektir. Tüm uygulamalar sarı acı baklanın vejetasyon periyodunun başlangıcında toplam bakteri sayısının, aktinobakteri sayısının ve oligotrofik bakteri sayısının azalmasına neden olmuştur. Diflufenicanın tek başına uygulanması durumunda nitrogenaz aktivitesinin arttığı tespit edilmiştir. Bu araştırma sonuçları toğrağa denenen herbisitlerin bulaşmasının dehidrogenaz ve asit fosfataz aktivitelerinde yüksek düzeyde duyarlılığa yol açtığını göstermiştir. Dehidrogenaz aktivitesi ile sayıları azalan mikroorganizma grupları arasında yakın ilişki bulunduğu tespit edilmiştir. Diflufenicanın tek başına uygulanmasının biyolojik toprak özellikleri üzerine çok düşük düzeyde olumsuz etkide bulunması sonucunda kirletici unsurlara diğer uygulamalara göre toprak çevresine de düşük düzeyde olumsuz etkilerinin olacağı sonucuna ulaşılmıştır.

Anahtar Kelimeler: Aktif maddeler; Herbisitler; Mikroorganizma sayıları; Baklagil bitkileri; Toprak enzim aktivitesi

(C) Ankara Üniversitesi Ziraat Fakültesi

\section{Introduction}

The cultivation of leguminous plants has a wide range of advantages, including the production of atmospheric nitrogen, the recovery of nutrients washed out into deeper soil layers by means of the long root system, improvement of the soil structure by leaving air tracts, and increasing the sorption capacity of the soil complex and the content of humus by leaving a large mass of crop residues (Galbally et al 2010). Soil nitrogen-fixing bacteria play an important role in leguminous plant productivity (Angelini et al 2013) as well as for other crops. In spite of many advantages of leguminous plants, there is not much interest in the production of these species in Poland, as the area where these crops are sown amounts to only $1 \%$ of the total crop area (GUS 2014). Leguminous plants tend to increase the number of weeds, due to their slow initial growth. Therefore, agronomists tend to use chemical methods of controlling weeds, and they continue to extend the range of herbicides added to the soil. Consequently, the accumulation of various contaminants in soil often deteriorates its properties, especially its bioactivity, including the process of biological nitrogen fixation by bacteria symbiotic with leguminous plants.

Herbicides are chemical compounds which affect life in the soil (Singh \& Ghoshal 2010). Being substances with high bioactivity, they may cause an imbalance in the quantity and quality of soil microorganisms. When herbicides are applied in recommended doses the inhibitory effect on microorganisms is transient (Adhikary et al 2014). Zain et al (2013) found a transient negative effect on soil microorganisms in an oil palm plantation even when a double dose of herbicides was applied. The biodegradation of pesticides can take place along different metabolic pathways. It is connected with the structure and properties of the preparation applied, and the environmental conditions. Regarding the latter, the availability of oxygen, chemical properties of soil and the enzymatic potential from individual microorganisms inhabiting a particular soil play a vital role in the biodegradation of plant protection compounds (Arbeli \& Fuentes 2007). Investigations revealed that adaptation of microorganisms to herbicide treatment occurs after several weeks of application, which appeared as fluctuations of soil enzyme activities (Sebiomo et al 2011).

Crop protection products applied to soil may have direct and indirect effects on the functioning of soil enzymes. Bielińska et al (2014) indicate that the direct effect consists in the influence on the extracellular enzyme activity. On the other hand, the indirect effect consists in the impact of pesticides on enzyme biosynthesis by soil microorganisms, as well as on the composition of the population of soil microorganisms (increasing/decreasing the population of microorganisms producing 
extracellular enzymes) and on the plant root systems (the state of symbiosis, production of root secretions, releasing enzymes from dead roots).

In order to assess the influence of the degree of soil contamination with herbicides, biological tests are used, including the number of soil microorganisms and enzyme activity (Sharma \& Suri 2011).

The aim of the study was to assess how selected active ingredients of herbicides, applied to yellow lupine, affect the nitrogenase activity, the populations of selected groups of microorganisms (total number of bacteria, copiotrophic bacteria, oligotrophic bacteria, actinobacteria and fungi), the activity of soil enzymes (dehydrogenases activity (DHA), acid phosphatase activity (PAC)) and their sensitivity (RS-soil resistance) to the tested preparations.

\section{Material and Methods}

\subsection{Experimental design}

Studies were conducted in 2011 and 2012 on plots of Brody Agricultural Experimental Station of the Department of Agronomy, which belongs to Poznań University of Life Sciences $\left(52.25895^{\circ} \mathrm{N}, 16.17874^{\circ}\right.$ E, $93 \mathrm{~m}$ a.s.1.). The yellow lupine (Lupinus luteus L.) cultivar of Mister was sown in plots of $28 \mathrm{~m}^{2}(4 \times 7 \mathrm{~m})$.
The experimental design was split block with four replications. Soil experimental plots, according to the FAO/WRB classification, were haplic luvisols. The granulometric composition of the soil ranged from light clayey sands to strong sands deposited on light clays. Parts smaller than $0.002 \mathrm{~mm}$ diameter make up $6 \%$ (loamy sand). The groundwater level rose in the period of excessive waterlogging. However, the groundwater usually occurred at a depth of $2 \mathrm{~m}$. The content of organic substance in the soil used in the experiment was $1.6 \%$, and the soil $\mathrm{pH}$ was 6.0 . The content of macroelements in amounts of pure components were as follows; $\mathrm{N}, 98.9 \mathrm{~kg} \mathrm{ha}^{-1}, \mathrm{P}, 65.8$ $\mathrm{mg} \mathrm{kg}{ }^{-1}, \mathrm{~K}, 226.6 \mathrm{mg} \mathrm{kg}^{-1}, \mathrm{Mg}, 69.0 \mathrm{mg} \mathrm{kg}^{-1}$. In the spring, mineral NPK fertilisation was applied at an amount of 40-60-60 kg ha-1 (188 $\mathrm{kg} \mathrm{ha}^{-1}$ ammonium nitrate and $250 \mathrm{~kg} \mathrm{ha}^{-1}$ Agrafoska P-K 24-24). Some local climatic data for experimental area are presented in Table 1.

Soil samples were collected from four variants. The samples differed in the type of herbicides used for yellow lupine cultivation. The doses of herbicides were optimal and recommended for these crops. One of the plots was the control sample, where no pesticide was used, while the other three differed in the type of active substances (Table 2). Diflufenican (2',4'-difluoro-2-[ $\alpha, \alpha, \alpha$-trifluoro-m-tolyloxy] nicotinanilide) is an active ingredient of Legato 500

Table 1- Meteorological conditions in 2011 and 2012 at experimental site

\begin{tabular}{lrrrrrr}
\hline \multirow{2}{*}{ Month } & \multicolumn{3}{c}{ Temperature $\left({ }^{\circ} \mathrm{C}\right)$} & \multicolumn{3}{c}{ Precipitation $(\mathrm{mm})$} \\
\cline { 2 - 7 } & $1961-2010$ & 2011 & 2012 & $1961-2010$ & 2011 & 2012 \\
\hline January & -1.6 & 0.9 & -1.9 & 40.3 & 73.9 & 42.6 \\
February & -0.6 & -3.5 & -0.2 & 32.7 & 47.9 & 26.1 \\
March & 2.8 & -5.7 & -2.5 & 39.1 & 20.0 & 12.0 \\
April & 8.0 & 8.8 & 8.0 & 37.2 & 22.9 & 15.4 \\
May & 13.2 & 14.8 & 14.4 & 57.1 & 77.2 & 69.8 \\
June & 16.5 & 16.0 & 17.3 & 64.1 & 163.0 & 125.3 \\
July & 18.2 & 19.2 & 20.1 & 81.2 & 194.6 & 67.3 \\
August & 17.6 & 18.7 & 19.1 & 66.0 & 60.1 & 51.5 \\
September & 13.3 & 14.3 & 12.9 & 48.9 & 30.0 & 33.7 \\
October & 8.6 & 8.2 & 10.3 & 42.0 & 47.6 & 10.9 \\
November & 3.6 & 4.8 & 5 & 45.3 & 54.8 & 34.1 \\
December & 0.0 & -1.5 & 2.7 & 48.4 & 16.5 & 27.8 \\
\hline Average/sum & 8.3 & 7.9 & 8.8 & 602.3 & 808.5 & 516.5 \\
\hline
\end{tabular}


Table 2- Scheme of field experiment

\begin{tabular}{lll}
\hline Experimental variants & Doses of active substances $\left(\mathrm{g} \mathrm{ha^{-1 } )}\right.$ & Trade name of the herbicide \\
\hline Control (no herbicide) & 0 & - \\
Diflufenican & 100 & Legato $500 \mathrm{SC}$ \\
Diflufenican + s-metolachlor & $100+1152$ & Legato $500 \mathrm{SC}+$ Dual Gold $960 \mathrm{EC}$ \\
Diflufenican + metribuzin & $100+140$ & Legato $500 \mathrm{SC}+\mathrm{Sencor} 70 \mathrm{WG}$ \\
\hline
\end{tabular}

SC herbicide manufactured by Adama. Diflufenican is an active substance that belongs to the group of anilide herbicides. The half-life degradation is 1530 weeks, which seems relatively fast (Bending et al 2006). S-metolachlor (2-chloro- $N$-2-ethyl-6methylphenyl-N-[(1S)-2-methoxy-1-methylethyl] acetamide) is an active substance in Dual Gold 960 EC herbicide manufactured by Syngenta. Metribuzin (4-amino-6-tert-butyl-3-(methylthio)as-triazin-5(4H)-one) is an active substance in Sencor $70 \mathrm{WG}$ herbicide manufactured by Bayer Crop Science. Metribuzin has been found to be a substance with short half-life degradation in the surface soil layer, but high mobility into deeper soil layers and consequently a high potential to transfer into groundwater were also observed (Pot et al 2011). S-metolachlor is characterized by movement in and out of the soil matrix, and can reach ground and surface water (Zemolin et al 2014).

Each time 14-18 individual samples were collected from a particular experimental variant, and they were used for a representative mixed sample. Soil samples were collected to analyse four terms, which were related to the consecutive stages of yellow lupine growth and doses of herbicides applied. The samples were collected at the following terms: before sowing (BBCH 0), during emergence (BBCH 10-13), at the beginning of flowering (BBCH 51-69), and after harvest.

\subsection{Nitrogen fixation measurements}

The activity of nitrogenase was assessed as acetylene reduction activity (ARA) at the beginning of flowering of plants. The methodology of nitrogenase activity measurements was based on Sawicka (1983), Niewiadomska \& Sawicka (2002) and LorencPlucińska et al (2013). The results of nitrogenase activity were expressed in $\mathrm{nmol} \mathrm{C}_{2} \mathrm{H}_{4}$ plant $\mathrm{h}^{-1}$.

\subsection{Soil enzymatic activity analyses}

The analyses of the enzymatic activity of soil in different variants were based on the colorimetric method applied to measure the dehydrogenase activity (DHA), where 1\% TTC (triphenyl tetrazolium chloride) was used as a substrate. The measurement took place after 24-hour incubation at $30{ }^{\circ} \mathrm{C}$ and a wavelength of $485 \mathrm{~nm}$, and it was expressed in mmol TPF (triphenyl formazan) $\mathrm{kg}^{-1}$ DM $24 \mathrm{~h}^{-1}$ (Thalmann 1968).

The biochemical analyses of soil involved the determination of activities of acid (EC 3.1.3.2) phosphomonoesterases (PAC) with the method developed by Tabatabai \& Bremner (1969). The activities were determined with disodium p-nitrophenyl phosphate tetrahydrate used as a substrate after $1 \mathrm{~h}$ of incubation at $37{ }^{\circ} \mathrm{C}$ at a wavelength of $400 \mathrm{~nm}$. The results were converted into mmol PNP (p-nitrophenol) $\mathrm{kg}^{-1} \mathrm{DM} \mathrm{h}^{-1}$ (LorencPlucińska et al 2013).

\subsection{Microbial analyses}

The samples were collected from the soil under the plants, from inter-rows, at a depth of $15-20 \mathrm{~cm}$. The number of microorganisms was measured with the method of pour plate dilution developed by Koch on appropriate agar medium in five replications. The mean number of colonies was calculated per dry weight of soil in the following way; the total number of bacteria was measured on a ready MerckStandard agar after 72 hours of incubation at 25 ${ }^{\circ} \mathrm{C}$; the number of fungi was measured on Martin (1950) medium after five days of incubation at 24 ${ }^{\circ} \mathrm{C}$; the number of copiotrophs was measured on NB medium after five days of incubation at $25^{\circ} \mathrm{C}$; the number of oligotrophs was measured on DNB medium (Ohta \& Hattori 1980) after five days of 
incubation at $25{ }^{\circ} \mathrm{C}$; the number of actinobacteria was measured on Pochon medium after five days of incubation at $25^{\circ} \mathrm{C}$ (Grabińska-Łoniewska 1999).

The level of contamination of the herbicides in the soil was analysed based on the soil resistance (RS) index (Equation 1).

$R S=1-\frac{2\left|D_{0}\right|}{C_{0}+\left|D_{0}\right|}$

Where; $C_{0}$, soil resistance under natural conditions over time $\mathrm{t}_{0} ; P_{0}$, resistance of soil subjected to pressure over time; $D_{0}=C_{0}-P_{0}$ (Orwin \& Wardle 2004).

\subsection{Statistical analysis}

The results were statistically analysed with the aid of Statistica 10.0 software. In order to compare the mean values of the biological parameters at individual terms of analyses and the influence of selected herbicides, two-way analysis of variance was used $(\alpha=0.05)$. It was followed by detailed Tukey's test (post-hoc Tukey HSD). Principal component analysis (PCA) was used to analyse the biological activity data resulting from the effect of herbicides at individual stages of yellow lupine development.

\section{Results and Discussion}

\subsection{Soil microorganisms}

The mean values of the results of the two-year study on the influence of different active substances of herbicides on the number of selected groups of soil microorganisms in yellow lupine cultivation were analysed statistically. The two-way analysis of variance revealed that the analysed factors had a highly significant influence $(\alpha=0.001)$ on the dynamics of variation in the number of selected groups of soil microorganisms, i.e. total number of bacteria, actinobacteria, and oligotrophic bacteria. The analysis did not reveal an influence of the factors on the number of fungi or copiotrophic bacteria (Table 3).

The results showed that the crop protection products applied in the experiment disturbed the
Table 3- F test statistics and significance levels of two-way analysis of variance for the number of selected groups of microorganisms and enzymes with type of herbicide and term of analysis fixed factors $(* * *, P=0.001 ; * *, P=0.01 ; *, P=0.05 ; n s$, not statistically significant)

\begin{tabular}{llll}
\hline Parameter & Herbicides & Term & Interaction \\
\hline \multicolumn{4}{c}{ Microorganisms } \\
\hline Total number bacteria & $1.01^{\mathrm{ns}}$ & $3.06^{\mathrm{ns}}$ & $2.31^{\mathrm{ns}}$ \\
Actinobacteria & $16.72^{* * *}$ & $133.0^{* * *}$ & $14.68^{* * *}$ \\
Fungi & $0.9^{\mathrm{ns}}$ & $8.3^{* * *}$ & $0.44^{* *}$ \\
Copiotrophic bacteria & $1.16^{\mathrm{ns}}$ & $2.21^{\mathrm{ns}}$ & $1.55^{\mathrm{ns}}$ \\
Oligotrophic bacteria & $1.17^{\mathrm{ns}}$ & $42.02^{* * *}$ & $2.4^{*}$ \\
\hline \multicolumn{4}{c}{} \\
\hline Enzymes \\
Acid phosphatase (PAC) & $5.3^{* * *}$ & $74.60^{* * *}$ & $4.7^{* * *}$ \\
Nitrogenase & $43.16^{* * *}$ & - & - \\
\hline
\end{tabular}

microbial balance of all the microorganisms. Variations in the populations of the microorganisms (total number of bacteria, actinobacteria, fungi, oligotrophic and copiotrophic bacteria) depended on the preparation applied and the term of analysis.

The analysis of the influence of the applied crop protection products on the total number of bacteria revealed a significant decrease in the population of these groups of soil microorganisms during plant emergence. In the variant where diflufenican and s-metolachlor were simultaneously used, the number of bacteria dropped by $73 \%$ as compared with the control sample. There was a similar decrease in the population of this group of microorganisms in the variant where diflufenican was combined with metribuzin. The smallest response in the total number of bacteria was observed when diflufenican was applied separately; the population dropped by $27 \%$ in comparison with the non-herbicide samples (Table 4).

The application of diflufenican and its combination with the other active substances significantly inhibited the proliferation of another group of microorganisms, i.e. actinobacteria. There was a highly significant inhibitory effect of the pesticides before sowing, immediately after their application. The use of the herbicide 
containing diflufenican as the active ingredient caused a decrease in the population of this group of microorganisms by $92 \%$. On the other hand, diflufenican combined with s-metolachlor and diflufenican combined with the herbicide containing metribuzin reduced the population of this group of microorganisms by $82 \%$ and $46 \%$, respectively, as compared with the control sample. In all the variants there was a noticeable increase in the population of actinobacteria during plant flowering. However, in variants where herbicides had been applied the population of actinobacteria was lower than in the control, uncontaminated soil sample (Table 4).
The actinobacteria were the most sensitive to the products applied, because during the whole vegetation the pesticides caused the number of actinobacteria to drop below the level noted in the uncontaminated control soil sample. Moreover, the decrease in the number of actinobacteria caused by the application of the herbicides may have resulted from the high toxicity of metabolites formed by the transformation of diflufenican, s-metolachlor and metribuzin. According to Niewiadomska et al (2011), both actinobacteria and oligotrophic bacteria belong to the 'eco-group' of microorganisms, which indicate soil fertility. When crop protection

Table 4- The number of selected groups of microorganisms in soil under yellow lupine analysed in different experimental variants and terms (mean values $\pm \mathrm{SE}$; different letters denote significant differences at level $\alpha=0.05$ among experimental variants within certain parameters and terms)

\begin{tabular}{|c|c|c|c|c|}
\hline \multirow{2}{*}{ Experimental variants } & \multicolumn{4}{|c|}{ Term of analysis } \\
\hline & Before sowing & Emergence & Beginning of flowering & After harvesting \\
\hline \multicolumn{5}{|c|}{ Total number of bacteria (cfu $\left.10^{5} \mathrm{~g}^{-1} \mathrm{DM}\right)$} \\
\hline Control & $12.88 \pm 3.4^{\mathrm{f}}$ & $33.79 \pm 9.4^{\mathrm{b}}$ & $42.56 \pm 8.7^{\mathrm{a}}$ & $7.98 \pm 1.1^{\mathrm{e}}$ \\
\hline Diflufenican & $21.41 \pm 3.8^{\mathrm{de}}$ & $24.57 \pm 2.2^{\mathrm{d}}$ & $28.25 \pm 10.3^{\mathrm{cd}}$ & $15.20 \pm 7.7^{\mathrm{de}}$ \\
\hline Diflufenican + s-metolachlor & $18.97 \pm 3.9^{\mathrm{e}}$ & $8.80 \pm 2.9^{\mathrm{g}}$ & $28.00 \pm 3.4^{\mathrm{cd}}$ & $19.21 \pm 3.3^{\mathrm{de}}$ \\
\hline Diflufenican + metribuzin & $34.42 \pm 1.7^{\mathrm{b}}$ & $14.89 \pm 1.6^{\mathrm{f}}$ & $26.60 \pm 3.8^{\mathrm{cd}}$ & $30.40 \pm 8.8^{\mathrm{c}}$ \\
\hline \multicolumn{5}{|c|}{ Actinobacteria $\left(\mathrm{cfu} 10^{5} \mathrm{~g}^{-1} \mathrm{DM}\right)$} \\
\hline Control & $103.08 \pm 6.6^{\mathrm{d}}$ & $155.83 \pm 7.8^{\mathrm{c}}$ & $459.54 \pm 15.6^{\mathrm{a}}$ & $35.72 \pm 2.6^{\mathrm{f}}$ \\
\hline Diflufenican & $8.65 \pm 0.6^{\mathrm{g}}$ & $83.57 \pm 7.4^{\mathrm{de}}$ & $308.11 \pm 11.3^{\mathrm{b}}$ & $13.68 \pm 3.0^{\mathrm{g}}$ \\
\hline Diflufenican + s-metolachlor & $18.22 \pm 4.3^{\mathrm{g}}$ & $40.3 \pm 6.7^{\mathrm{f}}$ & $439.04 \pm 36.3^{\mathrm{a}}$ & $26.74 \pm 2.9 \mathrm{f}^{\mathrm{g}}$ \\
\hline Diflufenican + metribuzin & $51.29 \pm 6.1^{\mathrm{e}}$ & $67.27 \pm 7.7^{\mathrm{e}}$ & $80.67 \pm 4.6^{\mathrm{de}}$ & $12.54 \pm 2.9^{\mathrm{g}}$ \\
\hline \multicolumn{5}{|c|}{ Fungi (cfu $\left.10^{4} \mathrm{~g}^{-1} \mathrm{DM}\right)$} \\
\hline Control & $0.37 \pm 0.6^{\mathrm{d}}$ & $1.40 \pm 0.4^{\mathrm{d}}$ & $6.40 \pm 0.6^{\mathrm{a}}$ & $2.60 \pm 0.7^{\mathrm{cd}}$ \\
\hline Diflufenican & $1.12 \pm 1.1^{\mathrm{d}}$ & $3.30 \pm 1.3^{\mathrm{c}}$ & $1.10 \pm 0.1^{\mathrm{d}}$ & $3.40 \pm 0.1^{\mathrm{c}}$ \\
\hline Diflufenican + s-metolachlor & $1.86 \pm 0.8^{\mathrm{d}}$ & $2.30 \pm 1.3^{\mathrm{d}}$ & $3.40 \pm 0.8^{\mathrm{c}}$ & $4.80 \pm 0.3^{\mathrm{b}}$ \\
\hline Diflufenican + metribuzin & $2.66 \pm 0.6^{\mathrm{cd}}$ & $5.40 \pm 1.1^{\mathrm{ab}}$ & $3.70 \pm 0.2^{\mathrm{c}}$ & $3.80 \pm 0.7 \mathrm{c}$ \\
\hline \multicolumn{5}{|c|}{ Oligotrophic bacteria $\left(\mathrm{cfu} 10^{5} \mathrm{~g}^{-1} \mathrm{DM}\right)$} \\
\hline Control & $48.35 \pm 9.8^{\mathrm{d}}$ & $5.08 \pm 1.4^{\mathrm{hi}}$ & $76.46 \pm 11.6^{\mathrm{ab}}$ & $21.28 \pm 6.2^{\mathrm{fg}}$ \\
\hline Diflufenican & $12.39 \pm 9.7^{\mathrm{h}}$ & $5.13 \pm 1.7^{\mathrm{h}}$ & $85.12 \pm 12.4^{\mathrm{a}}$ & $17.86 \pm 9.9^{\mathrm{h}}$ \\
\hline Diflufenican + s-metolachlor & $21.21 \pm 2.8^{\mathrm{fg}}$ & $1.46 \pm 0.6^{\mathrm{i}}$ & $73.92 \pm 9.1^{\mathrm{ab}}$ & $24.11 \pm 8.5^{\mathrm{f}}$ \\
\hline Diflufenican + metribuzin & $29.94 \pm 4.4^{\mathrm{e}}$ & $4.36 \pm 1.2^{\mathrm{i}}$ & $63.27 \pm 12.2^{\mathrm{c}}$ & $60.05 \pm 10.9^{\mathrm{c}}$ \\
\hline \multicolumn{5}{|c|}{ Copiotrophic bacteria $\left(\mathrm{cfu} 10^{5} \mathrm{~g}^{-1} \mathrm{DM}\right)$} \\
\hline Control & $29.23 \pm 9.6^{\mathrm{b}}$ & $20.71 \pm 9.1^{\mathrm{bc}}$ & $53.11 \pm 7.5^{\mathrm{a}}$ & $8.74 \pm 1.2^{\mathrm{bc}}$ \\
\hline Diflufenican & $12.76 \pm 5.2^{\mathrm{bc}}$ & $28.23 \pm 7.7^{\mathrm{b}}$ & $66.67 \pm 4.0^{\mathrm{a}}$ & $23.94 \pm 4.3^{b}$ \\
\hline Diflufenican + s-metolachlor & $17.85 \pm 4.8^{\mathrm{bc}}$ & $10.26 \pm 1.3^{\mathrm{c}}$ & $21.28 \pm 5.1^{\mathrm{b}}$ & $28.62 \pm 5.2 b$ \\
\hline Diflufenican + metribuzin & $27.70 \pm 4.3^{\mathrm{b}}$ & $16.35 \pm 2.8^{\mathrm{bc}}$ & $12.58 \pm 1.2^{\mathrm{bc}}$ & $22.80 \pm 2.5^{\text {bc }}$ \\
\hline
\end{tabular}

cfu, colony form unit 
products are applied, their metabolites may disturb the growth of actinobacteria and thus reduce the fertility of the soil environment. The negative influence of herbicides on the proliferation of soil bacteria, including actinobacteria, was also observed by Sebiomo et al (2011), who studied atrazine, s-metolachlor, paraquat and glyphosate. Kucharski \& Wyszkowska (2008) presented similar conclusions when they observed that the number of soil microorganisms decreased significantly after sulfosulfuron herbicide had been applied.

In the present study, no statistically significant effect of the tested substances on the growth of fungi was observed. On the other hand, when the yellow lupine was flowering, the use of herbicides caused a decrease in the fungal population. Lipşa et al (2010) reported that metolachlor caused a larger reduction of number of fungi in the soil. On the other hand, Anastasi et al (2012) stated that fungi play a major role in all ecosystems as decomposers. They are important participants in degradation of the major organic pollutants in the soil, such as herbicides. According to Baćmaga et al (2014) and Cycoń \& Piotrowska-Seget (2009), some species of microorganisms use herbicides as a source of carbon and nutrients. The properties of microorganisms to degrade pesticides partly reduce toxic substances. In consequence, this may not only have a positive effect on the yield but may also improve the biological properties of soil. It is noteworthy that the preparations applied in our research additionally stimulated the number of fungi during the emergence of yellow lupine. The stimulating effect of herbicides on the proliferation of fungi was also observed by Crouzet et al (2010), who studied the effect of mesotrione applied to soil at doses of $0.45-45 \mathrm{mg} \mathrm{kg}^{-1}$, and by Zabaloy et al (2010), who researched the influence of dichlorophenoxyacetic acid applied to soil at doses of 1 to $10 \mathrm{mg} \mathrm{kg}^{-1}$. On the other hand, Martinez et al (2008) found that sulfentrazone did not affect the number of fungi in soil. Meanwhile, the study by Giri et al (2011) suggested that application of pesticides may create a great problem for beneficial soil microorganisms and microbial transformation of several primary and secondary nutrients. They observed that pesticides such as endosulfan and mancozeb exerted a detrimental effect on transformation of sulphur, whereas 2,4-D created a favourable beneficial effect on sulphur transformation in the soil environment.

Similarly to other groups of microorganisms, oligotrophic bacteria also responded with variation in their population in the soil, which had been induced by the application of crop protection products. The negative influence of the xenobiotics before sowing, immediately after their application and during the plants' emergence was observed. However, at the stage of yellow lupine flowering there was a noticeable increase in this group of microorganisms in the variant where diflufenican and the mixture diflufenican with s-metolachlor had been applied. On the other hand, after yellow lupine had been harvested, there was a significant increase in this group of microorganisms in the variant where diflufenican had been applied in a mixture with metribuzin (Table 4).

The field doses of herbicides also disturbed the balance of copiotrophic bacteria in the soil. Although the results were not statistically confirmed, the population of these microorganisms decreased before the plants' emergence and while they were flowering, especially in the variants where diflufenican had been applied in combination with s-metolachlor or metribuzin. When diflufenican was applied separately, it proved to be the least toxic, as during the emergence and flowering of yellow lupine the population of copiotrophs increased by $40 \%$ and $28 \%$, respectively, as compared with the uncontaminated soil sample (Table 4). The results of the study presented by Sahoo et al (2016) indicated that pretilachlor at the recommended dose can be safely used for controlling grassy weeds in rice fields, but application of pretilachlor at a higher dose, in general, significantly reduced the number of bacteria, actinobacteria, fungi, nitrogen fixers, and microbial biomass carbon.

\subsection{Nitrogen fixation}

A statistically significant influence of plant protection chemicals on nitrogenase activity was noted in 
all treatments of the field experiment in which herbicides were applied. The highest nitrogenase activity was observed for application of diflufenican in comparison to the control, while the application in combination with metribuzin and s-metolachlor inhibited the analysed enzyme (Figure 1). Khan et al (2006) also recorded a reduction of nitrogenase activity after the pre-emergent application of methabenzthiazuron (MBT), terbutryn, and linuron to chickpea cultivation. Similar results were noted by Angelini et al (2013), who revealed a negative effect of a series of active ingredients (including s-metolachlor) on the diazotrophic bacterial community and soil nitrogenase activity. Moreover, they also noted a prolonged negative effect on the next culture, even at one year after application.

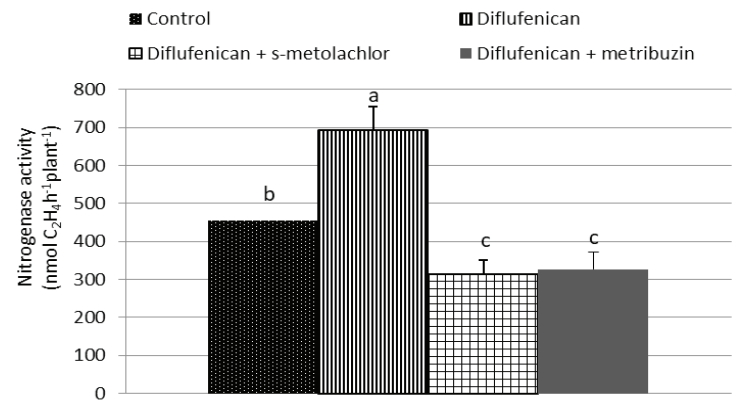

Figure 1- The effect of herbicides on nitrogenase activity (means $\pm \mathrm{SE}$; different letters denote significant differences at level $\alpha=0.05$ )

\subsection{Soil enzymes}

When diflufenican and the mixture of diflufenican with s-metolachlor or with metribuzin were used, they significantly affected the activity of the soil enzymes, i.e. dehydrogenases and acid phosphatase (Table 3). Soil enzymes can be treated as indicators of changes in the soil environment caused by application of several xenobiotics. These enzymes are involved in many processes of biodegradation of natural and anthropogenic compounds, such as herbicides (Wang et al 2009; Baćmaga et al 2012; Baćmaga et al 2014).

The crop protection products applied in the experiment had a negative influence on the dehydrogenases activity (DHA) at all the terms of analyses. The results revealed that when the plants were at the full flowering stage and after the harvest, this parameter was most negatively influenced by the crop protection products combining diflufenican with s-metolachlor or with metribuzin (Figure 2). The activity of soil dehydrogenases was previously found to be the most sensitive detector of the soil microorganisms' condition, due to their occurrence in all living cells (Gomez et al 2009). Dehydrogenases are intercellular enzymes whose activity is closely correlated with microbial activity (Bello et al 2013). Our results indicate very high sensitivity of dehydrogenases to the soil contamination caused by the application of diflufenican, the mixture of diflufenican with s-metolachlor or the mixture with metribuzin. The highest inhibition of DHA was noted in the variant when diflufenican with metribuzin was applied. Baćmaga et al (2014) obtained similar results in their research on the activity of these enzymes in soil contaminated with metazachlor. Kucharski et al (2008) noted the negative effect of herbicides (Harpun 500SC, Faworyt 300, Akord $180 \mathrm{OF}$ ) on the dehydrogenase activity. Cycon et al (2013) also described the reduced activity of these enzymes caused by the application of napropamide.

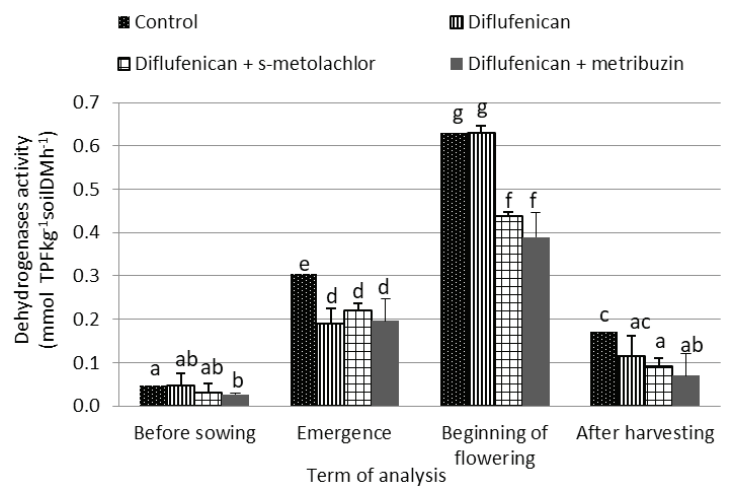

Figure 2- The effect of herbicides on dehydrogenases activity in different terms (means $\pm \mathrm{SE}$; different letters denote significant differences at level $\alpha=0.05$ )

Physiological processes in microorganisms can be affected by pesticides and their metabolites, and in turn modify the activity of soil enzymes (Hussain 
et al 2009; Romero et al 2010). However, the separate application of glyphosate and diflufenican in loam and sandy loam did not change the soil microbial activity, while inhibition was noted for the combination of the above-mentioned substances (Tejada 2009).

Phosphatase was another enzyme used for testing the soil quality. It is responsible for the mineralisation of organic phosphorus compounds (Rahmansyah et al 2009). In our experiment, acid phosphatase also reacted negatively to the crop protection products applied in the experiment. However, its activity decreased at the stage of the plants' emergence only in the variant where diflufenican had been applied separately and in the combination with s-metolachlor. At the other terms of analyses the herbicides stimulated the activity of the enzyme. The application of the preparations increased the acid phosphatase activity by $14 \%$ at the flowering stage and by $31 \%$ after the harvest, as compared with the control sample (Figure 3). Baćmaga et al (2012) obtained similar results in their research on the influence of carfentrazone and a mixture of diflufenican + mesosulfuron-methyl + iodosulfuron-methyl-sodium.

The ratio of sensitivity (RS) values (Table 5) varied depending on whether diflufenican had been applied separately or in combination with s-metolachlor or in combination with metribuzin.

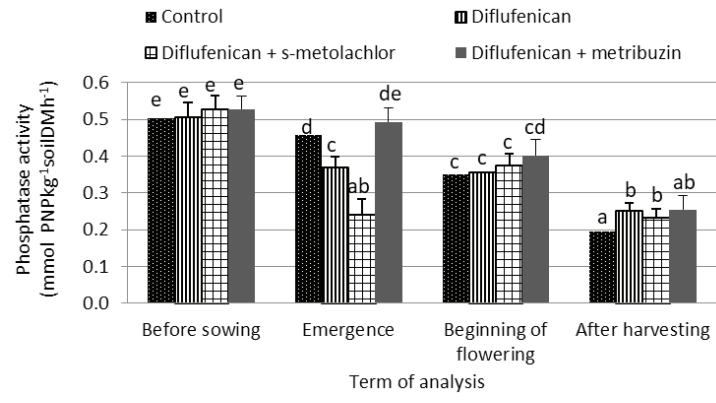

Figure 3- The effect of herbicides on acid phosphatase activity in different terms (means \pm $\mathrm{SE}$; different letters denote significant differences at level $\alpha=0.05$ )

The highest RS level was observed for dehydrogenases (0.959) when the plants were flowering in the variant where diflufenican had been applied in combination with s-metolachlor, whereas the lowest RS value was observed for acid phosphatase (0.022) immediately after the application of diflufenican in combination with metolachlor.

Regardless of the herbicides applied, dehydrogenases exhibited greater sensitivity to contamination than acid phosphatases, and it did not decrease during the vegetation of yellow lupine. On the other hand, the sensitivity of acid phosphatases depended on the variant applied and the term of application (Table 5). When diflufenican was applied separately, the enzymes exhibited low sensitivity

Table 5- Resistance of soil (RS) enzymes to contamination with herbicides (PAC, acid phosphatase activity; DAH, dehydrogenases activity; different letters denote significant differences at level $\alpha=0.05$ among experimental variants within certain parameters and terms)

\begin{tabular}{lllll}
\hline \multirow{2}{*}{ Experimental variants } & \multicolumn{4}{c}{ Term of analysis } \\
\cline { 2 - 5 } & \multicolumn{5}{c}{ Before sowing } & Emergence & Beginning of flowering & After harvesting \\
\hline Diflufenican & $0.358^{\mathrm{ab}}$ & $0.531^{\mathrm{ab}}$ & $0.817^{\mathrm{a}}$ & $0.519^{\mathrm{ab}}$ \\
Diflufenican + s-metolachlor & $0.022^{\mathrm{b}}$ & $0.568^{\mathrm{c}}$ & $0.568^{\mathrm{ab}}$ & $0.486^{\mathrm{ab}}$ \\
Diflufenican + metribuzin & $0.347^{\mathrm{ab}}$ & $0.529^{\mathrm{ab}}$ & $0.488^{\mathrm{ab}}$ & $0.137^{\mathrm{b}}$ \\
\hline \multicolumn{5}{c}{ RS index of DAH } \\
\hline Diflufenican & $0.939^{\mathrm{a}}$ & $0.704^{\mathrm{ab}}$ & $0.954^{\mathrm{a}}$ & $0.534^{\mathrm{ab}}$ \\
Diflufenican + s-metolachlor & $0.792^{\mathrm{a}}$ & $0.564^{\mathrm{ab}}$ & $0.959^{\mathrm{a}}$ & $0.810^{\mathrm{a}}$ \\
Diflufenican + metribuzin & $0.911^{\mathrm{a}}$ & $0.295^{\mathrm{c}}$ & $0.787^{\mathrm{ab}}$ & $0.723^{\mathrm{ab}}$ \\
\hline
\end{tabular}


immediately after the treatment, before the plants were sown (0.358). However, later, when the plants were flowering, the sensitivity increased (0.817). On the other hand, the contamination of the soil with diflufenican combined with s-metolachlor did not cause such high sensitivity of acid phosphatase as when diflufenican was applied separately. The RS reached the highest value during the plants' emergence (0.580), but later the sensitivity decreased. In the variant where diflufenican and metribuzin were applied, the highest value of the ratio was observed during the plants' emergence and flowering, i.e. 0.529 and 0.488 , respectively, but later it dropped to 0.137 (Table 5).

The soil ecosystem is considered to be stable if it can oppose stress-inducing factors and quickly recovers the state of balance (Orwin \& Wardle 2004; Griffiths \& Philippot 2013). Soil stability is usually estimated according to resistance and resilience. In our study the RS value was calculated by estimating the resistance of the soil contaminated with diflufenican separately and diflufenican combined with s-metolachlor as well as diflufenican combined with metribuzin.

The imbalance in the dehydrogenases activity proved to be more sensitive to the effect of the herbicides than phosphatase. Griffiths \& Philippot (2013) emphasised that long-term application of xenobiotics can have an impact on defensive mechanisms of the soil and furthermore cause an imbalance of the maintenance of soil biological stability.

The results of the influence of the herbicides on the bioactivity of soil were illustrated by means of principal component analysis (PCA). The analysis highly $(58.55 \%)$ explained the dependences occurring in the soil environment under yellow lupine due to the application of diflufenican as well as diflufenican combined with s-metolachlor and diflufenican combined with metribuzin. At all the terms of analyses, there was a strong correlation between the number of microorganisms and soil enzyme activities. Moreover, there was a positive correlation between the effect of the crop protection products and the bioactivity of soil when yellow lupine was flowering. At the other terms of analyses, there were negative correlations (Figure 4).

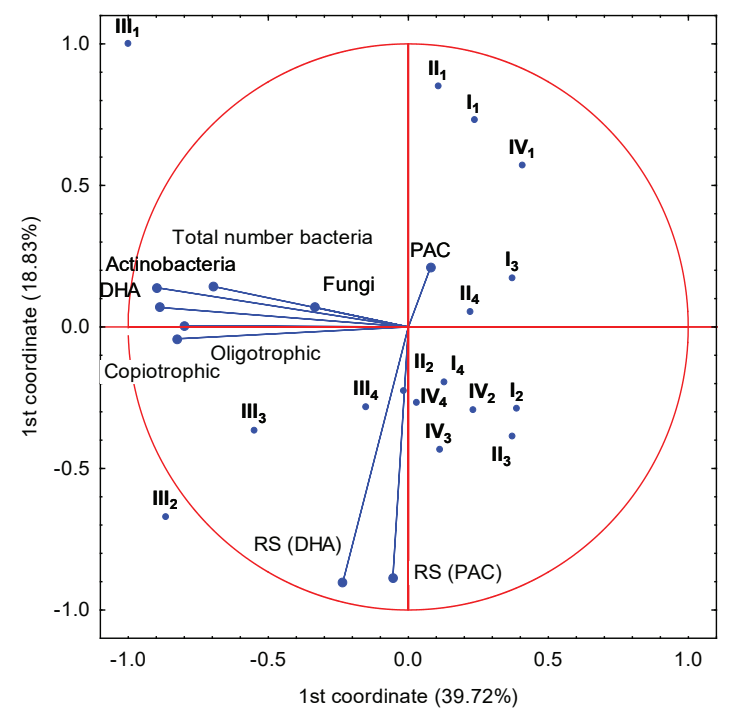

Figure 4- The dependence between the population of microorganisms and soil enzymatic activity for all variants with herbicides at the terms of analyses; I, before sowing; II, emergence; III, beginning of flowering; IV, after harvesting; 1, control; 2, diflufenican; 3, diflufenican + s-metolachlor; 4, diflufenican + metribuzin; PAC, acid phosphatase; DHA, dehydrogenases; RS, soil resistance

Overall, soil fertility can be affected by active substances of herbicides, due to changes of the number of soil bacteria. The quality of soil is inextricably associated with the microbial transformations. Therefore, in order to better understand their effect, it is necessary to make a detailed analysis of the microbial processes they manage (Bello et al 2008; Saha et al 2012; Baćmaga et al 2014). Our results indicate that the crop protection products applied in the experiment, diflufenican and the product in combination with s-metolachlor or metribuzin, applied to yellow lupine had various effects on the groups of soil microorganisms, and the effects depended on the product applied and on the term of analyses. S-metolachlor herbicide is 
one of the three most used herbicides in the world in the chloroacetanilide class. This herbicide has high toxicity and can be leached, representing a powerful source of groundwater pollution (Liu et al 2001). Martins et al (2007) stated that only four microorganisms in soil have the ability to degrade this xenobiotic.

\section{Conclusions}

Diflufenican and its combinations with s-metolachlor or metribuzin applied to yellow lupine caused a statistically significant biological imbalance in the soil, reducing the total number of bacteria as well as the number of actinobacteria and oligotrophic bacteria at the beginning of vegetation, immediately after the treatment. The experiment revealed a stimulatory role of diflufenican used separately on nitrogenase activity, while in combination with other products an inhibitory effect was observed. The research revealed very high sensitivity of dehydrogenases and acid phosphatase to the soil contamination caused by the application of diflufenican, the mixture with s-metolachlor as well as the mixture with metribuzin. The field doses of the xenobiotics used in the research significantly reduced the dehydrogenase activity during the whole vegetation season. The dehydrogenase activity values were closely correlated with reduced populations of the groups of microorganisms.

In summary, the application of certain active ingredients alone or as a mixture should be considered according to the potential effect on soil microbiological activity and further soil fertility.

\section{References}

Adhikary P, Shil S \& Patra P S (2014). Effect of herbicides on soil microorganisms in transplanted chilli. Global Journal of Biology, Agriculture and Health Science 3(1): 236-238

Anastasi A, Tigini V \& Varese G C (2012). The Bioremediation Potential of Different Ecophysiological Groups of Fungi. Soil Biology 32: $29-49$
Angelini J, Silvina G, Taurian T, Ibáñez F, Tonelli L M, Valetti L, Soledad Anzuay M, Ludueña L, Muñoz V \& Fabra A (2013). The effects of pesticides on bacterial nitrogen fixers in peanut-growing area. Archives of Microbiology 195: 683-692

Arbeli Z \& Fuentes C L (2007). Accelerated biodegradation of pesticides: An overview of the phenomenon, its basis and possible solutions and a discussion on the tropical dimension. Crop Protection 26: 17-33

Baćmaga M, Boros E, Kucharski J \& Wyszkowska J (2012). Enzymatic activity in soil contaminated with the Aurora 40WG herbicide. Environmental Protection and Engeneering 38(1): 91-102

Baćmaga M, Kucharski J, Wyszkowska J, Borowik A \& Tomkiel M (2014). Responses of microorganisms and enzymes to soil contamination with metazachlor. Environmental Earth Science 72: 2251-2262

Bello D, Trasar-Capeda C, Leirós M C \& Gill-Sotres F (2008). Evaluation of various tests for diagnosis of soil contamination by 2,4,5-trichlorophenol $(2,4,5-$ TCP). Environmental Pollution 156: 611-617

Bello D, Trasar-Capeda C, Leirós M C \& Gill-Sotres F (2013). Modification of enzymatic activity in soils of contrasting $\mathrm{pH}$ contaminated with 2,4-dichlorophenol and 2,4,5-trichlorophenol. Soil Biology and Biochemistry 56: 80-86

Bending G D, Lincoln S D \& Edmondson R N (2006). Spatial variation in the degradation rate of the pesticides isoproturon, azoxystrobin and diflufenican in soil and its relationship with chemical and microbial properties. Environmental Pollution 139: 279-287

Bielińska J, Futa B \& Mocek-Płóciniak A (2014). Soil enzymes as bio-indicators of soil health and quality. Libropolis Press, Lublin

Crouzet O, Batisson I, Besse-Hoggan P, Bonneomoy F, Bardot C, Poly F, Bohatier J \& Mallet C (2010). Response of soil microbial communities to the herbicide mesotrione: A dose-effect microcosm approach. Soil Biology and Biochemistry 42: 193-202

Cycoń M \& Piotrowska-Seget Z (2009). Changes in bacterial diversity and community structure following pesticides addition to soil estimated by cultivation technique. Ecotoxicology 18(5): 632-642

Cycoń M, Wójcik M, Borymski S \& PiotrowskaSeget Z (2013). Short-term effects of the herbicide napropamide on the activity and structure of the soil microbial community assessed by the multi approach analysis. Applied Soil Ecology 66: 8-18 
Galbally I E, Meyer M C P, Wang Y P, Smith C J \& Weeks I A (2010). Nitrous oxide emissions from a legume pasture and the influences of liming and urine addition. Agriculture, Ecosystems and Environment 136: $262-272$

Giri P K, Saha M, Halder M P \& Mukherjee D (2011). Effect of pesticides on microbial transformation of sulphur in soil. International Journal of Plant Animal and Environmental Science 1(2): 115-121

Gomez E, Ferreras L, Lovotti L \& Fernandez E (2009). Impact of glyphosate application on microbial biomass and metabolic activity in Vertic Arggiudoll from Argentina. European Journal of Soil Biology 45: 163-167

Grabińska-Łoniewska A (1999). Laboratory classes in general microbiology. Warsaw Technology University Press, Warsaw

Griffiths B S \& Philippot L(2013). Insights into the resistance and resilience of the soil microbial community. FEMS Microbiological Review 37: 112-129

GUS (2014). Central Statistical Office of Poland. Agriculture in 2014. Retrieved in March, 24, 2015 from http://www.stat.gov.pl

Hussain S, Siddique T, Saleem M, Arshad M \& Khalid A (2009). Impact of pesticides on soil microbial diversity, enzymes and biochemical reactions. Advances in Agronomy 102: 159-200

Khan M S, Zaidia A \& Rizvib P Q (2006). Biotoxic effects of herbicides on growth, nodulation, nitrogenase activity, and seed production in chickpeas. Communications in Soil Science and Plant Analysis 37(11-12): 1783-1793

Kucharski J \& Wyszkowska J (2008). Biological properties of soil contaminated with the herbicide Apyros 75 WG. Journal of Elementology 13(3): 357371

Lipşa F D, Ulea E, Chiriac I P \& Coroi I G (2010). Effect of herbicide s-metolachlor on soil microorganisms. Lucrări Ştiinţifice Seria Agronomie 53(2): 110-113

Liu W P, Liu H J, Zheng W \& Lu J H (2001). Adsorption of chloroacetanilide herbicides on soil structural influence of chloroacetanilide herbicidefor their adsorption on soils its components. Journal of Environmental Science 13(1): 37-45

Lorenc-Plucińska G, Walentynowicz M \& Niewiadomska A (2013). Capabilities of alders (Alnus incana and A. glutinosa) to grow in metal-contaminated soil. Ecological Engineering 58: 214-227
Martin J P (1950). Use of acid, rose Bengal and streptomycin in the plate method for estimating soil fungi. Soil Science 69: 215-233

Martinez C O, Silva C M M S, Fay E F, Maia A H N, Abakerli R B \& Durrant L R (2008). Degradation of the herbicide sulfentrazone in a Brazilian typic hapludox soil. Soil Biology and Biochemistry 40: 879-886

Martins P F, Martinez C O, De Carvalho G, Irajara P, Azevedo A A, Pileggi S A, De Melo I S \& Pileegi M (2007). Selection of microorganisms degrading S-metolachlor herbicide. Brazilian Archives of Biology and Technology 50(1): 153-159

Niewiadomska A \& Sawicka A (2002). Effect of carbendazim, imazethapyr and thiram on nitrogenase activity, number of microorganisms in soil and yield of hybrid lucerne (Medicago media). Polish Journal of Environmental Studies 6: 737-744

Niewiadomska A, Sawińska Z \& Wolna-Maruwka A (2011). Impact of selected seed dressing on soil microbiological activity in spring barley cultivation. Fresenius Environmental Bulletin 20(5a): 1252-1261

Ohta A \& Hattori T (1980). Bacteria sensitive to nutrient broth medium in terrestrial environments. Soil Science of Plant Nutrition 26: 99-107

Orwin K H \& Wardle D H (2004). New indices for quantifying the resistance and resilience of soil biota to exogenous disturbance. Soil Biology and Biochemistry 36: 1907-1912

Pot V, Benoit P, Le Menn M, Eklo O-M, Sveistrup T \& Kvaerner J (2011). Metribuzin transport in undisturbed soil cores under controlled water potential conditions: experiments and modelling to evaluate the risk of leaching in a sandy loam soil profile. Pest Management Science 67: 397-407

Rahmansyah M, Antonius S \& Sulistinah N (2009). Phosphatase and urease instability caused by pesticides present in soil improved by grounded rice straw. Journal of Agricultural and Biological Sciences 4(2): 56-62

Romero E, Fernández-Bayo J, Díaz J M C \& Nogale R (2010). Enzyme activities and diuron persistence in soil amended with vermicompost derived from spent grape marc and treated with urea. Applied Soil Ecology 44: 198-204

Saha S, Dutta D, Karmakar R \& Ray D P (2012). Structuretoxicity relationship of chloroacetanilide herbicides: relative impact on soil microorganisms. Environmental Toxicology and Pharmacology 34: 307-314 
Sahoo S, Adak T, Bagchi T B, Kumar U, Munda S, Saha S, Berliner J, Jena M \& Mishra B B (2016). Nontarget effects of pretilachlor on microbial properties in tropical rice soil. Environmental Science and Pollution Research 23(8): 7595-7602

Sawicka A (1983). The ecological aspects of dinitrogen fixation. Poznań Agricultural University Annals, Scientific Dissertations 134: 1-57

Sebiomo A, Ogundero V W \& Bankole S A (2011). Effect of four herbicides on microbial population, soil organic matter and dehydrogenase activity. African Journal of Biotechnology 10: 770-778

Sharma P \& Suri C R (2011). Biotransformation and biomonitoring of phenylurea herbicide diuron. Bioresources Technology 102: 3119-3125

Singh P \& Ghoshal N (2010). Variation in total biological productivity and soil microbial biomass in rainfed agroecosystems: Impact of application of herbicide and soil amendments. Agriculture, Ecosystem and Environment 137: 241-250

Tabatabai V \& Bremner J (1969). Use of p-nitrophenyl phosphate for assays of soil phosphatase activity. Soil Biology and Biochemistry 1: 301-307

Tejada M (2009). Evaluation of soil biological properties after addition of glyphosate, diflufenican and glyphosate+diflufenican herbicides. Chemosphere 76: 365-373

Thalmann A (1968). Zur methodik der bestimmung der dehydrogenase aktivität in boden mittels triphenyltetrazoliumchlorid (TTC). Landwirtschaftliche Forschung 21: 3-4

Wang Q, Zhou D \& Cang L (2009). Microbial and physicochemical properties of soil contaminated with herbicide Triflurotox 250 EC. Polish Journal of Environmental Studies 13: 223-231

Zabaloy MC, Garland JL \& GomezMA(2010). Assessment of the impact of 2,4-dichlorophenoxyacetic acid (2,4D) on indigenous herbicide degrading bacteria and microbial community function in an agricultural soil. Applied Soil Ecology 46: 240-246

Zain N M M, Mohamad R B, Sijam K, Morshed M M \& Awang Y (2013). Effects of selected herbicides on soil microbial populations in oil palm plantation of Malaysia: A microcosm experiment. African Journal of Microbiology Research 7(5): 367-374

Zemolin S R, Avila L A, Cassol G V, Massey J H \& Camargo E R (2014). Environmental fate of s-metolachlor-a review. Planta Daninha 32(3): 655664 